Ministerstwo Nauki

i Szkolnictwa Wyższego

Digitalizacja archiwalnych numerów czasopisma naukowego Analecta Cracoviensia 1-24 (1969-1992)

i ich publikacja w otwartym dostępie - zadanie finansowane w ramach umowy 672/P-DUN/2017 ze środków

Ministra Nauki i Szkolnictwa Wyższego przeznaczonych na działalność upowszechniającą naukę

\title{
ST. JÓN OF HÓLAR: CANON LAW AND HAGIOGRAPHY IN MEDIEVAL ICELAND *
}

In the mid-eleventh century, 1056 A.D., Archbishop Adalbert of Hamburg-Bremen consecrated Isleifr Gizurrsson as the first resident bishop of Iceland ${ }^{1}$. Thus, after a long period of difficult and erratic missionary beginnings, the bleak, majestic island just south of the Arctic circle became incorporated into the hierarchical structure of the Church. Only

* General bibliography for the early medieval history of the Church in Iceland will be found, e. g., in H. Jedin's Handbuch der Kirchengeschichte, III 1: Die mittelalterliche Kirche..., by F. Kempf et al. (Freiburg-Basel-Wien 1966) ch. 30, pp. 261-2 (= pp. 521-2 of the English translation by A. Briggs, The Church in the age of feudalism; London-New York 1969), and in the entries for Iceland by W. Göbell, Lexikon für Theologie und Kirche, 2nd ed. 5 (1960) 801, or by M. P. Jakobson, New Catholic Encyclopedia 7 (1967) 322. K. Maurer's posthumous work Uber Altnordische Kirchenverfassung und Eherecht (Vorlesungen über Altnordische Rechtsgeschichte II; Leipzig 1908) still remains worthwhile. - The present writer, not being sufficiently familiar with Scandinavian languages, has not consulted articles and major treatises in any of them. As for the corpus of the Old Norse sources and sagas, he must rely on the English version of the bilingual edition by G. Vigfusson and F. Y. Powell, Origines Islandicae, I (Oxford 1905), , in spite of all its shortcomings ...a monumental work": cf. H. Hermansson, Old Icelandic Literature (Islandica 24; Ithaca, N. Y. 1935) p. 28. For more recent editions and bibliography of the texts chiefly used in this paper see the entries in Kulturhistorisk Leksikon for nordisk middelalder 7 (Copenhagen 1962) s. vv. Hungrvaka, by M. M. Lárusson (col. 88-9): Islendigabók by B. Sigfusson (494-5), Ións saga helge, by Lárusson (617-18); also G. Turville-Petre, Origins of Icelandic Literature (Oxford 1952). - I wish to thank Mr. George Davis of the Documents Department, General Library of the University of California, Berkeley, for his kind assistance in translating some Old Norse passages where a closer scrutiny of the text in Origines Islandicae seemed indicated. Finally, in quoting from the sagas, I have not retained all the studied English archaisms of that text.

1 Adam of Bremen, Gesta Hammaburgensis ecclesiae pontificum 4. 36, ed. B. Schmeidler (Scriptores rerum German. in usum scholarum, 3rd ed. 1917) p. 273; I have not seen the new edition by W. Trillmich (Darmstadt 1961). Hungrvaka c. 2, in Biskupa sögür I (Copenhagen 1858) pp. $61-2$; c. 1.3 in Orig. Island. I p. 428; I have not seen the new edition by J. Helgason, in Byskupa sögür I (Copenhagen 1938). 
a few years earlier, Pope Leo IX had confirmed to Adalbert his prerogatives as apostolic vicar and legate, after the model of St. Boniface, for the peoples of the north and the east, beyond the confines of his own metropolitan province 2 . In those years, Adalbert could indeed proudly style himself ,legate of the holy Roman and Apostolic see, unworthy minister of the church of Hamburg, and archbishop of all the nations of the North" 3.

Isleifr established his see, rather precariously, at his ancestral homestead and church of Skálholt: it was only his son and successor Gizurr (1082-1118) who had it enacted as law that the bishop's see should always be at Skálholt ${ }^{4}$. He built a cathedral church and dedicated it to St. Peter ${ }^{5}$. The creation of the second bishopric took place in a quite different setting early in the twelfth century. When Gizurr had been bishop for twenty years or so, the men from the "Northland" area of the isle asked him for a second see in the country so that Iceland would never be without a bishop. After much deliberation and consultation the choice fell upon the priest Jón Ögmundsson, who had been educated from his boyhood by Bishop Isleifr, traveled as a young deacon on the European continent in pursuit of his studies, and was admired for his gifts by all. „And he went abroad with letters from Gizurr the bishop and then went to see Pope Paschalis. And he was consecrated bishop by Archbishop Asser of Lund in Skane, two nights before the mass of Philip and James [29 April]. Then Jón went to Iceland and set up his bishop's chair at Hólar..." ${ }_{6}$

Thus far the anonymus author of the Hungrvaka, i. e. the Lives of the early bishops of Skálholt. From the synchronisms which Ari Thorgilsson (Ari Fródi), the father of Icelandic historiography, presents in the Islendigabók (c. 1122-1132), the year of St. Jón's consecration can be fixed at 1106 when he was fifty-four years old ${ }^{7}$. It was a new era for the churches of the North. The hold of Hamburg and the German

2 Leo IX. JL 4290; new cdition in Diplomatarium Danicum I 2: 1053-1169, ed. L. Weibull and N. Skyum Nelsen (Copenhagen 1963) No. 1, pp. 1-5; for the reference to $\mathrm{St}$. Boniface see the text p. 4 lin. 4-7. On Adalbert's canonical position and ambitions see especially H. Fuhrmann, Studien zur Geschichte mittelalterlicher Patriarchate (III), in Zeitschrift der Savigny-Stiftung für Rechtsgeschichte, Kan. Abt. 41 (1955) 95-183, at $120-70$ (p. 147 n. 154 on the authenticity of JL 4290, established by Kehr).

3 Diplomatarium Danicum I 2, No. 8 (= Adam, Gesta 3. 76 p. 222).

4 Ari Thorgilsson, Íslendigabók 10. 4 in Orig. Island. I p. 302.

5 Hungrvaka 2. 6, ibid. p. 435 (= Biskupa sögür I p. 67 c. 6). It is chiefly on the strength of these texts that Maurer, Altnordische Kirchenverfassung (note* supra) pp. 53ff. argued for considering Isleifr the last of the missionary bishops rather than the first residential bishop of Iceland.

6 Hungrvaka 2. 9 in Orig. Island. I p. 43 (= Biskupa sögür I p. 68-9 c. 6); shortened in Diplom. Dan. I 2, No. 36 col. 1.

' Islendigabók 10. 11 ed. cit. p. 304; cf. Diplom. Dan. loc. cit., editors' comments p. 81 . 
Reichskirche over the Scandinavian lands had been broken in the course of a complex historical development; it culminated in the action of Paschal II who elevated the see of Lund to become an archbishopric with metropolitan rights for all the northern kingdoms and islands ${ }^{8}$. Apparently the bishop of Skálholt in faraway Iceland was already aware of the news when he sent the bishop-elect abroad with his letters.

Much more detail on the first bishop of Hólar is found in the Jóns Saga, which exists in several Old Norse recensions ${ }^{9}$. Like the lost Latin vita it renders, Jóns Saga was written by Gunnlaugr Leifsson, monk of Thingeyrar Abbey (d. 1218), soon after St. Jón's canonization ${ }^{10}$; that is, after the solemn translatio of his body from the tomb to an altar in the cathedral which his third successor, Bishop Brandr Saemundarson, performed on 3 March 1200, almost eighty years after the Saint's death (23 April 1121) ${ }^{11}$.

This is what Gunnlaugr tells us of St. Jón's voyage after his election 12: That summer the bishop-elect took ship with his retinue and friends and with Bishop Gizurr's letter and seal to bear witness of his errand. They arrived in Denmark after a good voyage and went at once to the place where Archbishop Asser was. It was rather late in the day and the archbishop was in church et evensong. (There follows a poetic story how Jón and his clerks stayed in the nave outside the choir and joined in the singing of vespers, and how because of the beauty of Jón's voice the archbishop forgot his own command not to turn around and look out of the choir). After the two had met and the archbishop had read Gizurr's letter, the matter of the new bishopric was discussed for several days.

8 Paschal II, JL 5994 (lost; reconstructed from a late tradition in the 14thcentury Chronicle of the Archbishops of Lund), JL 6335, ante 8 May 1104. Cf. Diplom. Dan. I 2 p. 64 (comments to No. 28) and No. 30; for recent discussion (since 1966) see W. Seegrü, Das Papsttum und Skandinavien bis zur Vollendung der nordischen Kirchenorganisation (Quellen und Forschungen zur Geschichte Schleswig-Holstein; Neumünster 1967) pp. 108-29, and the review by F. Kempf in Archivum historiae pontificiae 6 (1968) 446--52; N. Skyum-Nielsen, Das dänische Erabistum vor 1250, in Acta Visbyensia III: Visby-symposiet för historiska vetenskaper 1967 (Göteborg 1969) 113-38.

9 Two of these in Biskupa sögür I, only the first in Orig. Istand. I pp. 53467.

10 O. Widding, H. Beklrer-Nielsen, L. K. Shook, The Lives of Saints in Old Norse prose, in Mediaeval Studies 25 (1963) 294-337, at p. 317f.; and see the entries on St. Jón and his saga by Bekker-Nielsen and Widding in Bibliotheco. Sanctorum 6 (Rome 1965) 1045f.; D. C. C. Pochin Mould, in New Catholic Encyclopedia 7. 1092; M. M. Lárusson, in Kulturhistorisk Leksikon (note * supra) 7. 608-12, 617-18. Not seen: J. Helgason, Ión Ögmundsson clen hellige, in Norvegia sacra 5 (1925) $1-34$.

${ }_{11} \mathrm{H}$. Bekker-Nielsen, A note on two Icelandic saints, in Germanic Review 36 (1961) 108-9, dispels the widespread anachronistic notion of any national disregard for papal prerogatives being shown in the episcopal „canonizations" of Sts. Thorlák and Ión: the right to canonize was not formally reserved to the pope until considerably later.

12 Jóns Saga 7. 2-4 in Orig. Island. I pp. 546-8 (= Biskupa sögür I pp. 159 61), shortened in Diplom. Dan. I 2, Nos. 36 col. 2 and 37 col. 1. 
"Then the archbishop spoke thus to the bishop-elect: 'My very dear brother, I perceive that you have nearly all the qualities that befit a bishop... but on account of one matter that you have told me, that you have had two wives, I dare not consecrate you without the knowledge and permission of the pope himself. Now it is my counsel that you hasten to the pope, and I shall write a letter with my seal to acquaint the pope with your case. And if it goes as we hope and he allows you to take consecration, and me to perform it, then return here quickly and I shali joyfuliy bring to an end your errand" ". (In another recension 1.3, Jón presents letters from Bishop Gizurr ,and other chieftains of Iceland"; the archbishop speaks of the need for permission ,of the apostolic see", and uses a Latinizing term: "If he [the lord pope] has granted you dispensation [hann dispenseri med thér]".)

Next we read ${ }^{14}$ of the bishop-elect's visit in Rome (to the lord pope in the curia, $i$ kuriam, as the other recension has it), where ,holy Paschal the second of that name" was pope. St. Jón presented all his errancl and showed the archbishop's letter and seal, which acquainted the pope with the whole state of the case. When the pope had seen the writings, "he granted the grace that had been humbly requested" and directed the bishop-elect to go and see Archbishop Asser, to whom he wrote under his seal, "giving him leave to consecrate the holy Jón bishop". (The other recension stresses that Pope Paschal acted supported by God's guidance, and again uses Latinizing terminology: Paschalis pape; ,from his curia postulig... a letter with his bulla”; ,dispenserir with blessed Jón electo", etc.)

There follows, aiter the pope's blessing, Jón's return to Archbishop Asser, with a further joyful sojourn, both before and after the consecration on the third of the Kalends of May.

It seems that the account of the bishop of Hólar's consecration as told in the Jóns Saga has never been critically examined by Church historians. Matters might be different, had not the Bollandists excluded St. Jon from the Acta Sanctorum at the time the first volume for March (1668) was in preparation. The brief remark we read there ( 3 mart.) is certainly unworthy of their own standards of hagiographic scholarship: Jonas Ogmundus episcopus Holanus, they say, will not be included

13 In Biskupa sögür I p. 232f. c. 20, shortened in Diplom. Dan. I 37 col. 2.

1. Jóns Saga 7. 5-6 in Orig. Island. I p. 548f. (= Biskupa sögür I p. 161 c. 9); the other recension in Biskupa sögür I p. 233f. c. 21; Diplom. Dan. I 2, Nos. 37, 38 cols. 1 and 2 (both shortened). 
because the only available source for him is Arngrim - this means Arngrimur Jónsson the Learned (1568-1648) — and ,homini a Catholica fide averso fidere non licet"; he is to be set aside ,dum certiora monumenta proferentur" 15. (As an interesting Lutheran counterpart of this piece of bigotry, we read in Finnur Jónsson's Ecclesiastical History of Iceland 16 : ,Jonas Oegmundinus ... in sanctorum numerum annis post mortem 77 puritate religionis deficiente a nostratibus relatus..."). Nothing seems to have come of the Latin translation of Jóns Saga which the great collector of Icclandic antiquities, Árni Magnússon (1663-1730), prepared at the beginning of the eighteenth century for the Bollandists from one of Gunnlaugr's Old Norse recensions. Magnússon's autograph and a copy exist in Copenhagen ${ }^{17}$; there is no mention of either in the Bibliotheca hagiographica latina. Thus the second national saint of Iceland in fact the oldest, even though the translatio of St. Thorlák Thórhalisson of Skilholt (1133-1193), preceded that of St. Jon by two years ${ }^{10}$ - has remained largely unknown to western students of hagiography and, we should add, to historians of canon law, for whom the tale of Pope Paschal Il's writ of dispensation ought to be of considerable interest.

It is an undisputed fact of Iceland's church history that well into the thirteenth century nearly all its bishops were married, as were of course deacons, priests, and other clergy ${ }^{19}$. Efforts at introducing canonical legislation on celibacy, such as those made in 1153 by Cardinal Nicholas Breakspear when he was legate to Norway and Sweden 20, are not found in Iceland until much later. Against this background of insular custom, the few comments that have been made in passing on St. Jón's case merely point out that it differed from the normal situation of married bishops because there was a second marriage, and this ,seemed" to be contrary to a scriptural command or ,recommendation" 21 .

This comfortable explanation is wide of the mark. From the early days of Christianity the injunction of the Pastoral Epistles that a bishop, deacon, of priest be unius uxoris vir (1 Tim. 3.2, 12, Tit. 1. 5-6)

15. Acta Sanctorum, Martii I p. 109 in the Paris printing (1865).

1i Finni Johannaei Historia ecclesiastica Islandiae, I (Hafniae 1772) 327.

ii See Widding, Bekker-Nielsen, Shook, op. cit. (note 10 supra) 317.

1s De sancto Thorlaco, in Biskupa sögür I p. 403: „Haec translatio corporis s. Thorlaci anno quinto ab obitu ipsius facta est ..."; cf. Bekker-Nielsen s. v. Thorlák Thórhallsson, in New Catholic Encycl. 14. 140.

${ }_{19}$ Maurer, Altnordische Kirchenverfassung p. 317; S. Kalifa, Usages insolites dans les coutumiers ecclésiastiques et les premiers, ,droits chrétiens" d'Islande et de Norvège, in Etudes offertes à Jean Macqueron (Aix-en-Provence 1970), pp. $385-98$.

20 See Seegrün, op. cit. (note 8 supra) pp. 151f., $168 \mathrm{f}$.

21 Maurer loc. cit.: „... weil dem ein bestimmtes Gebot der Schrift entgegenzustehen schien"; Kalifa, op. cit. p. 393: Archbishop Asser ,ne contestait pas, en l'occurrence, le droit au mariage de Jon, mais sa seconde union légitime qui transgressait une recommandation paulinienne". Both authors cite 1 Tim. 3. 2. 
was taken as one of the strictest among the requirements which the catalogue of the regula apostoli had set up for holy orders ${ }^{22}$. The remarried widower was barred from ordination as digamus or bigamus, not because of any moral taint (we must forget modern usage, where „bigamy" always means two simultaneous married lives), but because the full sacramental meaning is lacking in any second marriage: the remarried man has "divided" his flesh and his marital union can no longer represent the mystical union of Christ with his Church ${ }^{23}$. As early as the fourth century, we therefore find an extension of the impediment - the irregularitas as it would later be called in the schools - to other cases that imply a divisio carnis: marriage to a widow, concubinage before marriage, and the like. At the same time we find an extension to minor orders of the clergy, but here the disciplinary practice remained variable: as a result, the canonical tradition of the early middle ages came to include texts of different intent. One among these, from the capitula of St. Martin of Braga (d. 579), would even allow lectors who had remarried, or married a widow, to be promoted to the subdiaconate ,if need be, but not beyond" (si forte necessitas sit, subdiaconus fiat, nihil autem supra) ${ }^{24}$.

In an earlier paper ${ }^{25}$ I have shown how many problems of interpretation would arise from this text for the canonists of the twelfth century, especially since it had, long before, been mislabelled as a decree of Pope Martin I (649-655), and also since-in the meantime the subdiaconate had become canonically assimilated to the major orders. The exegesis of „Pope Martin's” text led to long-drawn and often sharp controversies over the limits of papal and episcopal powers of dispensation. For the modern mind it may be difficult to appreciate, but our texts bear witness that the debate here grew as hot-tempered as in the more famous quarrels over dispensations from the vow of poverty or over papal interpretations of the Franciscan Rule.

Until we reach the last quarter of the twelfth century, the possibility of extending dispensation from bigamy to the higher orders - diaconate, priesthood, episcopacy — was not even contemplated from afar. Simon de Bisignano (c. 1177 - 79), the first canonist to ask the question ${ }^{26}$, an uero summus pontifex posset bigamum ad sacerdotium promouere, uel

22 For history and bibliography see J. Vergier-Boimond, Bigamie (irrégularité de), in Dictionnaire de droit canonique 2 (1947) 853-88. The early sources are assembled by Gratian, mainly in Dist. $26-28,33-34$, and discussed in the article cited infra (note 25), especially pp. 410-14.

${ }_{23}$ The locus classicus is St. Augustine, De bono coniugali c. 18 (21), in PL 40. 387-8, abridged in Glossa ord. on Tit. 1 and so quoted by Gratian D. 26 c. 2 24 Mart. Bracar. Capitula c. 43 (Opera ed. Barlow; New Haven 1950, p. 135), in Gratian D. 34 c. 18.

${ }_{25}$ S. Kuttner, Pope Lucius III and the bigamous archbishop of Palermo, in Medieval Studies presented to Aubrey Gwynn, S. J. (Dublin 1961), pp. 409-54.

26 See Kuttner, Pope Lucius... p. 424; full text p. 440. 
utrum esset sacerdos, si eum ordinaret de facto, shied away from answering it; after all, this meant for the pope openly to set aside the apostolic rule. A few years later, some author said the pope could grant such a dispensation but it was not known that he ever had done so; another held that he could not, ,although I have heard of such a dispensation" 27. The first concrete case was reported by Huguccio (c. 1188-90): „In our day”, he wrote, „Lucius III gave a dispensation for the priesthood to some bigamus in Sicily" 28. It was also Huguccio who lined up, not without hesitation, the main arguments from the doctrine of Peter's primacy for this extension of papal prerogative. His train of thought, including the caveat that it would not be fitting for the pope always to make use of his power, became the foundation for the predominant teaching ${ }^{29}$, although a line of dissenters can be cited down to the mid-thirteenth century ${ }^{\mathbf{3 0}}$.

Pope Lucius' precedent most probably was a dispensation given for Matthew of Salerno (d. 1193), the last chancellor of the Norman kings of Sicily ${ }^{31}$. In the tradition of the schools, however, Huguccio's report soon was embellished, and before the end of the twelfth century, the quidam bigamus in Sicilia had become the bigamous archbishop of $\mathrm{Pa}-$ lermo. This legendary case remained throughout the Middle Ages, and beyond, the stock example for exceptional dispensatory powers of the papacy ${ }^{32}$.

If we now return to Gunnlaugr's Life of St. Jón of Hólar, there can be little doubt that the story he tells of the dispensation granted by Pope Paschal II was modeled upon the contemporary canonistic discussions of the archbishop of Palermo's case. A hundred years earlier, in $1205 / 6$, it was literally unthinkable, given the state of development of doctrine, that Paschal should have written ,, under his seal" to the archbishop of Lund, instructing him to consecrate a bigamus. When even later in the thirteenth century some authors refused to believe the report

27 Ibid. pp. 424, 441-2.

28 Ibid. p. 433; Huguccio, Summa D. 34 c. 18 v.nihil autem supra: ,... nostris etiam temporibus Lucius tertius dispensauit cum quodam bigamo in Sicilia usque ad presbyteratum".

29 Pope Lucius... pp. $424-7$, texts pp. $442 \mathrm{ff}$.

30 Ibid. pp. $427-30,443 \mathrm{ff}$.

31 Ibid. 435-9. The evidence comes from Peter of Eboli, Liber ad honorem Augusti (c. 1195-6), a poem in praise of the Emperor Henry VI and full of venom against King Tancred and his chancellor; of the latter he writes:

Te sinus ecclesie contra decreta recepit:

Peccati bigamum non decet ara dei:

Te prece uel precio, sanctissime pape, fefellit ...

32 Pope Lucius..., pp. 431-5. 
of Pope Lucius' dispensation, or denied that holy orders so conferred could give the sacramental character, we can imagine what the reaction would have been a century before: Paschal's act would have been considered almost a deviation from the faith and probably caused an uproar similar to that which greeted his request in 1111 that the German bishops give up their regalia or, shortly afterwards, his grant of the ,pravilegium" to King Henry V.

But one can guess why Gunnlaugr found it necessary in his day to insert this circumstantial story of the papal dispensation. Among the many archaic traits of the early Icelandic Church, with its Eigenkirchen and its married bishops, we must also reckon the fact that the irregularity of the bigamus and the viduae maritus was obviously unknown. We read in the Life of St. Thorlák (1133-93) that his kinsmen urged him to take a wife and that he planned to marry a certain widow. ,It was not at that time greatly censured by the superiors if a priest took a widow to wife, though it is now forbidden". Thus the author of the Thorlaks Saga tells us early in the thirteenth century, and apparently he considers this a quite recent restriction ${ }^{33}$. Thorlak was visiting at the manor of the widow with his kinsmen, ready to ask for her hand, when ,a man of noble countenance" appeared to him in a dream and told him not to do so; ,there is another bride much higher in store for you and you shall take none other but her'". This was, of course, a prophecy of his future elevation to the bishopric of Skálholt. St. Thorlák never married at all, but the point was not that the marriage to a widowed lady would have barred him from orders.

In the case of St. Jón, his Saga simply tells us that he was twice married, that his first wife lived but a short while, and that from neither marriage children were known to have survived ${ }^{34}$. This short report follows immediately upon a section that speaks of Jon's exemplary service as a priest in the church of his ancestral estate: at this point, apparently no one was aware that by right he could not have been ordained to, or remained in, the priesthood. But after the canonization of 1200 the irregular status of the sainted bishop had somehow to be corrected. The Hungrvaka had mentioned his traveling south to Pope Paschal before his consecration by Archbishop Asser in Lund 35: such travel to Rome may or may not have been merely a topos, a literary borrowing from the lives of the first two Icelandic bishops, Isleifr and Gizurr, both of whom had

3 Thorláks Saga 4. 7 in Orig. Island. I p. 464-6 (= Biskupa sögür I p. 93 c. 5). Niaurer, Altnordische Kirchenverfassung p. 367 refers to this case, citing Lov. 21. 13-14, but apparently again unaware of the whole canonical tradition ( $\cdot$ f. notes 19,21 supra).

T4 Jóns Saga 5. 2 in Orig. Island. I p. $544(=$ Biskupa sögür I p. 93 c. 5).

:5upra at note 6. 
gone to see the pope - Leo IX and Gregory VII respectively - before their consecration ${ }^{36}$. In any event, here was a cue for Gunnlaugr the monk of Thingeyrar to insert the story of a papal dispensation in the Jóns Saga.

If our conjectural interpretation of the Saga is correct, it presupposes that a certain amount of canonical learning had been carried to the remote North by the beginning of the thirteenth century. To verify such an assumption, however, requires a greater knowledge of Icelandic cultural history than a canonist from an altogether different background could claim.

36 Hungrvaka 1. 3 in Orig. Island. I p. 428 and c. 2. 4, ibid. p. 434 (= Biskupa sögür I pp. 61 c. 2 and 67 c. 5). 